\section{EMBRYRIDDLE}

Aeronautical University

SCHOLARLY COMMONS
Journal of Aviation/Aerospace

Education \& Research

Volume 14

Number 3 JAAER Spring 2005

Article 8

Spring 2005

\title{
The Effects of Air Traffic Control Privatization on Operating Cost and Flight Safety
}

Anthony W. Adams

Follow this and additional works at: https://commons.erau.edu/jaaer

\section{Scholarly Commons Citation}

Adams, A. W. (2005). The Effects of Air Traffic Control Privatization on Operating Cost and Flight Safety. Journal of Aviation/Aerospace Education \& Research, 14(3). https://doi.org/10.15394/jaaer.2005.1521

This Article is brought to you for free and open access by the Journals at Scholarly Commons. It has been accepted for inclusion in Journal of Aviation/Aerospace Education \& Research by an authorized administrator of Scholarly Commons. For more information, please contact commons@erau.edu. 


\title{
THE EFFECTS OF AIR TRAFFIC CONTROL PRIVATIZATION ON OPERATING COST AND FLIGHT SAFETY
}

\author{
Anthony W. Adams
}

\begin{abstract}
The purpose of this study was to determine if privatization of the Air Traffic Control (ATC) System would cause a reduction in ATC operating cost and improve air traffic safety. An analysis was made to determine the effect privatization had on operating cost and air traffic safety involving the privatized ATC systems of Australia, Germany, New Zealand, and Switzerland. The study showed reduced operating cost and increased safety would result from corporate structuring of the ATC system. It was concluded that corporate style policy regarding personnel management and equipment procurement procedures would increase efficiency, which would reduce operating cost and increase ATC flight safety.
\end{abstract}

\section{STATEMENT OF THE PROBLEM}

Will the privatization of the Air Traffic Control System reduce operating cost and increase flight safety? Today, air transportation is the preeminent means for commerce ... among people (cited in Change, 1993). It has a tremendous impact on the U. S. economy through employment, revenue generation and as a purchaser of goods and services from supplier industries. A serious problem exists with the Air Traffic Control (ATC) system in the United States. It is the inability to acquire new modernized equipment to meet the demands of the air transportation industry. The ATC system handles seven million commercial flights carrying more than 475 million passengers a year utilizing technology that in some cases dates back to the 1940 s.

President Clinton's Administration's privatization proposal in 1994 contained provisions to restructure the nation's air traffic control system as a quasi-government corporation to be run like a private business. The proposal called for an air traffic control corporation that would be efficient, financially self-sufficient, financially able to respond to rapid change, and technologically superior. The ultimate goal was to operate the ATC system, currently run by the Federal Aviation Administration (FAA), more like a business, according to Transportation Secretary Federico Pena (Lenorovitz \& Phillips, 1994). The responsibility for air traffic control would be removed from the Federal Aviation Administration. The new United States Air Traffic Services (USATS) Corporation would be responsible for the operation of the air traffic control system. The FAA would retain the authority for issues concerning safety and national security. USATS would be governed by a board of directors selected by the President and confirmed by the Senate. The eleven members on the board would include a chief executive officer, the Transportation Secretary, the Defense Secretary and eight individuals representing system users from the commercial airlines, general aviation, and airports, as well as labor and business (Phillips, 1994).

This study analyzed the privatized ATC systems of Australia, Germany, New Zealand, and Switzerland to determine the feasibility of applying their systems to the United States. The study attempted to determine if privatization of the system would reduce operating cost and increase flight safety. Reduced cost and increased safety will result from the utilization of new state of the art equipment. Simpler policy to replace the multitude of rules and regulations governing personnel will result in cost reduction by adopting policy to attract, train, manage, and retain qualified personnel. This study is important because air traffic control plays a vital part in the transportation industry, which is the fastest mode for the movement of people and freight. Efficient air traffic control must exist to maintain the orderly and safe flow of air traffic. Modern high tech equipment must exist along with qualified personnel to operate and maintain safe operation of air traffic. The FAA employs about 38,000 people to operate and support the ATC system that requires nearly $80 \%$ of the agency's \$9-billion budget to function properly and safely (Phillips, 1994). Bureaucratic personnel and equipment 
procurement policy have prevented the FAA from procuring and using cutting-edge technology that would have improved economic efficiency. An improved efficient system is needed to replace the current system. The techniques and procedures demonstrated by the case studies of Australia, Germany, New Zealand, and Switzerland were presented as tested methods that could be implemented in the U.S. to create a safer and more economical ATC system.

The fact that there are only four countries utilizing privatized ATC systems does produce limitations. However, they do represent ideal working models of a similar but smaller system whose methods could be applied on a larger scale.

\section{THE REVIEW OF LITERATURE}

The literature relevant to the privatization include (1) some background books describing the history of ATC in the United States; (2) news reports on the government's proposal; (3) contemporary reports from magazines and periodicals; and (4) Federal Aviation Administration regulation and handbook publications.

\section{HISTORICAL OVERVIEW}

The history of the U. S. ATC and its funding is told in a couple of accounts. Two books, Bonfires to Beacons and Conquest of the Skies, describe the early days of ATC and the evolution of government involvement. Air traffic control first became necessary in areas around airports that became bottlenecks of air transportation, similar to other terminal areas for other modes of transportation. All flight operations begin and end at a terminal area, so the requirement to regulate and coordinate takeoffs and landings evolved.

ATC for enroute traffic was not needed because it could safely operate on a see-and-be-seen basis and because enroute congestion was not a problem. Air Traffic Control is defined as a service operated by an appropriated authority to promote safe, orderly, and expeditious flow of air traffic (FARs). The Air Traffic Control Handbook (2004) states that the primary purpose of the ATC system is to prevent a collision between aircraft (Air Traffic Control Handbook, 2004). Air traffic is defined as any aircraft operating in the air or on an airport surface, exclusive of loading ramps and parking ramps and parking areas (Federal Air Regulations, 2004). Air traffic control is concerned with (1) keeping aircraft safely separated while operating in controlled airspace, on the ground, during takeoff, during ascent, enroute and during approach and landing; and (2) providing preflight and in-flight services to all pilots (Kane, 1982).

Airway traffic control in the United States was developed by the early airlines during the late1920s and early 1930s. As a result of Depression-era budget restrictions, the Department of Commerce was unable to quickly form an air traffic control system and requested that the major airlines themselves take the initiative and develop a number of airway traffic control units (ATCUs) that would separate aircraft operating on the federal airways (Nolan, 2004). The federal government indicated that it would eventually take over and operate these ATCUs in the future. The private airline industry maintained the ATCU system until June 1937. The air traffic control system developed by the airlines caught on fast. As the volume of air traffic increased during the 1930s, the airlines collectively decided that a more central authority was needed to act like a traffic cop (Solberg, 1979). The airlines had jurisdiction over themselves but not over the ever-increasing non-airline traffic. Since the implications of air travel were normally interstate with no general relation or respect for state boundaries, it was only natural that the federal government be approached to be the authority. It was very receptive to being the ATC authority (Solberg, 1979). The government had been anxious to show gains in mastering air safety because it was under heavy public pressure generated by several airline crashes during the 1930s. The death of two prominent figures in air crashes, Notre Dame's football coach Knute Rockne and Senator Bronson Cutting, had brought air traffic control safety to the national level.

In June of 1937, the Department of Commerce began to acquire the ATCUs from the airlines and staffed them with federally certified controllers (Nolan, 2004). The name was also change to airway traffic control station (ACTS). This was the first time that the federal government became directly evolved with air traffic control. Prior to this, the only other involvement of the federal government in ATC took place in 1926 as a result of the Air Commerce Act of 1926. This Act provided for the establishment, maintenance, and operation of a civil lighted airway system and a low frequency radio navigation system in support of the early airmail service. In the interest of national defense, the Federal Government took over control tower operations at all major airports in November 1941. Now, for the first time, the federal government controlled the traffic at the airport along with the enroute traffic. The government also established flight service stations throughout the country to provide preflight and in-flight services to pilots.

The system continued to expand and modernize to meet the increasing demands of the aviation industry. During the 1950s, air traffic congestion at major cities gained national attention and aircraft near misses were being reported at an average of four per day. On June 30,1956 , the 
worst air crash in U. S. history occurred when a TWA Super Constellation collided with a United DC-7 in broad daylight over the Grand Canyon killing 128 people. This accident was a turning point for the air traffic control system (Wells, 1986).

Following this accident, the government ordered the development and implementation of new long-range radar equipment capable of surveillance of all airway traffic in controlled airspace. Controlled airspace is defined as airspace designated as such within which some or all aircraft may be subject to air traffic control (FARs, 2004). The 1956 accident led to the Airways Modernization Act of 1957 that provided for the development and the modernization of the national system of navigation and air traffic control. In the interest of air safety and the need to support the common needs of the military and civil aviation of the United States, the Federal Aviation Agency was created on August 23, 1958 (Wells, 1986). The agency was responsible for the use of navigable airspace and regulation of civil as well as military operations in such airspace. The agency was later downgraded to the Federal Aviation Administration (FAA) in April 1967 following the creation of the Department of Transportation. However, its responsibilities remained unchanged.

President Kennedy directed the FAA and the Department of Defense in 1961 to conduct a scientific and engineering review of U.S. navigational facilities to prepare a plan to ensure the efficient and safe control of all air traffic (Nolan, 2004). The review produced the introduction of the air traffic control radar beacon system (ATCRBS). A new era in air traffic control was launched with implementation of this system. The new system enabled the air controllers to electronically establish positive identification of the aircraft they were tracking on radar.

\section{PRESENT STATUS}

Presently, the ATC system is a vast network of facilities located in all 50 states, Guam, American Samoa, Panama, and Puerto Rico. There are three types of facilities: the air route traffic control centers, airport control towers including approach control, and flight service stations (FSS). There are 24 air route traffic control centers (ARTCCs), 75 Flight Service Stations (FSS), over 1000 radio navigational aids, 700 instrument landing systems (ILS), and 250 long-range and terminal radar systems.

Almost half of the agency's (FAA) work force of more than 52,000 people is engaged in some phase of air traffic control (Wells, 1994). An additional 12,000 technicians and engineers are required to install and maintain the various components of the system, such as radar, communications sites, and ground navigation aids (Wells, 1994). The primary purpose of the system today is the same as it was 70 years ago: safety. The United States is the only country where all air traffic, both military and civil, is controlled by a civil air traffic control system. The exception to this is special use airspace used exclusively for military training. Existing arrangements for joint civil and military use of the ATC system would be maintained with the new system (Phillips, 1994). Alexander Wells (1994) states that the U. S. ATC system is the largest and most advanced air traffic control and navigation system.

\section{PROPOSED CHANGES}

Privatization can involve a contract approach or a corporate approach method. Chang and Jones (1992) indicated that contracting for services is the privatization approach used in most western societies. This method is simple and has many advantages, but it may not always be cost effective (Chang \& Jones, 1992). The corporate approach to privatization would enable USATS to correct inefficiencies and bypass bureaucratic red tape that plagues the present ATC system. The Clinton Administration's proposal to create a federal air traffic control corporation essentially would shift responsibility from the FAA to the private sector - a major policy change designed to foster system modemization and increase efficiency without sacrificing safety (Phillips, 1994). As envisioned by the Administration, a United States Air Traffic Services (USATS) corporation would be a financially independent, autonomous organization within the Transportation Department (Phillips, 1994). Air traffic control, under the government's plan, would be removed entirely from the Federal Aviation Administration and the corporation would be empowered to develop its own rules pertaining to flight of aircraft within the ATC system. The FAA, however, would retain the authority to approve and implement such rules and continue to ensure regulatory compliance regarding operation of the overall system. Any substantial changes to airspace procedures would have to be approved by the FAA. Collogan (1994) noted that the creation of a more efficient ATC system was not the administration's primary objective. Collogan (1994) also contended that the principle reasons why the White House and Department of Transportation were pushing this idea so hard were (1) money and (2) public perception. Gilbert (1994) points out that the biggest backer of the proposal is the Air Transportation Association (ATA), which represents the nation's largest airlines, followed closely by the National Air Traffic Controllers Association (NATCA) and Professional Airway System Specialist (PASS), the unions that represent 
the controllers who operate the current ATC system and the technicians who maintain the equipment.

Phil Boyer (1994) of the Aircraft Owners and Pilots Association (AOPA) noted that the U. S. air traffic system has proven itself to be the safest and most efficient in the world. Boyer also indicated we should continue to make it better, rather than scrapping it (1994).

Gordon Gilbert (1994) reported that most interested parties agreed that the ATC system, as currently formed, suffered from serious procurement and funding problems. The industry is split on whether or not the administration's proposal would solve those problems. He also identifies the major supporters and opponents. Generally, the major airlines and the ATC controllers supported it, whereas the regional, commuters, and the general aviation sector did not. The Air Line Pilot Association remains neutral on the issue (Gilbert, 1994).

Facts on File (1993) reported on a recommendation that was released by a Special Presidential Commission that was formed in April 1993 to recommend ways to improve and reform the nation's troubled airline industry. The panel focused on the problems affecting the industry. One of its recommendations was the modernizing and partially privatizing the FAA. The panel concluded that removing the FAA from complete federal control would reduce cost and improve efficiency.

Existing procurement policies, both within the FAA and other departments of government, are chiefly to blame for the FAA's lethargy in updating the ATC system, according to proponents of a government owned-corporation (Phillips, 1994). Phillips (1994) reported that the corporation would be allowed to single-source work or products if cost, time considerations and efficiency justified such action. Air traffic control privatization issues have yet to be resolved in the U. S., but the experiences of some foreign systems show positive results (Hazelwood, 1994).

A crucial policy change for an ATC corporation would be its ability to borrow up to $\$ 15$ billion from private capital sources and the U.S. Treasury ... rather than rely on an annual congressional budget process ... a requirement that proponents of USATS claim is largely responsible for the agency's inability to modernize the A'TC network (Phillips, 1994). Dempsey (1992) found that not only was the system understaffed, but also many airports and navigational facilities were equipped with obsolete aging equipment. In addition, USATS would adopt policies to attract and retain qualified employees-an on going problem at the FAA because of the plethora of rules and regulations governing personnel (Phillips, 1994). It also would expand employee involvement in the operation of the organization; create a more flexible recruiting, hiring and placement system, and develop a new compensation schedule (Phillips, 1994). These articles demonstrate how privatization would decrease operating cost below present levels and increase safety.

A special report by Aviation Week \& Space Technology (May 16, 1994), presented studies of successful commercialized ATC corporations in Australia, Germany, New Zealand and Switzerland. New Zealand's Airways Corporation earned high marks for lowering operating cost and improving the nation's air traffic control services as the world's first fully commercial national air traffic control organization (Mecham, 1994). Mecham (1994) found that within the first year of its founding, Airways Corp. produced a profit of NZ\$4.2 million ( $\$ 2.3$ million U.S.). Prior to privatization, the ATC system was losing about NZ\$10 million ( $\$ 5.5$ million U.S.) a year. Profits since privatization have been consistent. In the last fiscal year, Airways reported a NZ\$11 million net profit (\$6.1 million U.S.). Proctor (1993) shows that privatization of ATC services in Australia had resulted in profits, reduced operating cost, increased efficiency and increased air safety. The arguments for privatizing ATC services are generally the same from country to country ... the most significant weakness being the hierarchical civil service structure, personnel recruitment polices, and the rigid procurement systems (Hazelwood, 1994).

The Government's National Commission to Ensure a Strong Competitive Airline Industry (cited in Change, 1993) suggested that the present U. S. ATC system was outmoded and was costing consumers billions of dollars each year in delays, and needed to be modernized. The Commission (1993) suggested that there was a fundamental inconsistency between the process of government and the operation of a 24-hour-a-day, high technology, capitalintensive ATC system. The individuals responsible for FAA activities are highly knowledgeable and motivated, but their talents and determination are stunted by the structure in which they are forced to operate (cited in Change, 1993). The method by which air traffic control is funded and implemented-through annual budget allocations subject to cuts and changes - virtually ensures that any planned "new" technology will be obsolete by the time it is operational (cited in Change, 1993). Cost overruns are inevitable for a procurement system where the basic process can take from five to ten years. An example of this is an ATC dataprocessing system installed in 1993 that was based on 1970 's technology. Initial research and development began 
in 1971, a contract was awarded in 1980, and installation took place in 1993.

\section{SUMMARY}

The literature reviewed contained the secondary data that was analyzed and used to prove or disprove the theory that privatization of the U. S. ATC system would result in (1) reduced cost through efficiency in personnel matters and equipment procurement and (2) increased air traffic safety for the same reasons. The literature provided descriptive case studies of the successful commercial ATC systems in Australia, Germany, New Zealand, and Switzerland. These studies provided successful working models with proven methods and procedures that could easily be applied to the U. S. system producing similar results.

\section{HYPOTHESIS}

Privatization of the ATC system will result in reduced operational cost and improved air traffic safety.

\section{METHOD}

This research project focused on the privatized ATC systems of Australia, Germany, New Zealand and Switzerland. These four systems were selected as representative working models similar to the system proposed by the Clinton administration.

The method used in this study assumes the findings in the study can be generalized to similar situations. The factor of size and volume of the U.S. ATC system as compared to the systems of this study could possibly affect the outcome and produce different results than indicated by this study.

A qualitative methodology was selected because most of the available current data was verbal. The research design was an ex post facto and causal comparison that involved a review of existing data. This method and design have been used in recent years to investigate effectiveness and efficiency within the United State's Department of Defense. It was also used to study the cultural adaptation of Germans and Americans in the Daimler Chrysler merger. The reported data for this study was secondary and collected from written descriptive and observational reports found in related aviation and business publications. The ex post facto method observes existing conditions and searches backwards through data for plausible causal factors (Leedy, 1993). Inductive reasoning utilizing the case study method was also utilized. The case study assumes that the findings in one case can be generalized to other situations of the same type (Shepard, 1981). It is ex post facto because secondary written data was collected after the fact. Convenience sampling was used because the countries selected were the only countries that had existing privatized ATC systems.
The ATC systems of these countries were looked at as working models with privatized systems similar to the one proposed by the Clinton administration. Causal studies seek to determine the effect that variables have on others or why certain outcomes are obtained (Emory \& Cooper, 1991). This type of research design was appropriate for this study because it was theorized that privatization techniques (the independent variable) would produce reduced operating cost, efficiency and increased safety (dependent variables). Independent variables were personnel management and equipment procurement techniques. They were categorized as non-probability because there was no way to guarantee that each element in the population was represented. Dependent variables were operating cost, operating efficiency, and flight safety. The techniques were government methods as opposed to commercial corporate style techniques.

Testing the hypothesis involved analyzing the asymmetrical relationship between the independent variable (IV) and the dependent variable (DV) to determine a cause and effect relationship. The feasibility of applying techniques and procedures from these foreign ATC systems to the U. S. ATC system was also analyzed. The observed results were used to prove or disprove the hypothesis. John Stuart Mill's cannons were utilized to eliminate inadequate causal arguments. John Stuart Mill was a nineteenth century economist, historian, and philosopher who developed a set of cannons to show if correlation exists between variables. They were: method of agreement; the negative method of agreement; and method of difference. The method of difference is a combination of the first two. It states that if there are two or more cases, and in one of them observation $\mathrm{Z}$ can be made, while in another it cannot; and if factor $\mathrm{C}$ occurs when observation $Z$ is made, and does not occur when observation $Z$ is not made; then it can be asserted that there is a causal relationship between $C$ and $Z$ (Emory \& Cooper). Emory and Cooper (1991) indicate that the cannons should only be used to eliminate inadequate causal arguments even though they have helped advance our understanding of the concept of causality. The canon (method of difference) was used to study the causal effects of the variables in this study on each other and to eliminate inadequate arguments.

Figure 1 provides a graphic display of the correlation or relationships that exist between the variables in this study. 


\section{RESULTS}

The results of the study do indicate that reduced operating cost and increased flight safety would result from privatization if a corporate approach were utilized. Analyzing the results reveals the following:

1. Four countries were used as subjects with ATC systems that have been privatized from two to seven years.

2. All countries have similar privatized ATC systems m structures involving quasi-government corporations.

3. All countries indicate that increased efficiency equates to increased ATC flight safety.

4. Three out of four countries reported an increase in efficiency.

5. Two indicated a decrease in ATC operating cost.

6. One subject showed an increase in ATC operating cost.

7. One subject indicated no change in operating cost.

8. All four employed corporate equipment techniques.

9. Three applied corporate personnel management techniques.

10. All have upgraded or are in the process of upgrading their ATC systems with modern state of the art equipment.

\section{DISCUSSION}

Increased flight safety was indicated but could not be measured or forecasted. ATC personnel of all the countries indicated that modern equipment made their systems safer. The study does indicate that increased efficiency would tend to enhance safety.

The results suggest that corporate personnel management techniques when applied equated to increased ATC safety and decreased operating cost most of the time through increased efficiency. The exact same was true when corporate procurement procedures for equipment were implemented. Operating cost either decreased or remained unchanged. The one subject that did not apply corporate style personnel management showed no change in safety and operating efficiency but did show an increase in operating cost last year.

Australia's 14 years of privatization has shown increased air safety and reduced operating cost by procuring new equipment and reducing personnel. The privatization of ATC in New Zealand lowered operating cost by reducing personnel and replacing outdated equipment. The reduction in personnel was over a seven-year period but the procurement of modern equipment was immediate. Privatization reversed annual operating losses into profits. German privatization, in existence since 1993, has not produced lower operating cost but did produce a drop in ATC air delays that was credited to ATC controller pay incentives and equipment modernization. Switzerland's ATC privatization experienced an increase in operating cost during its fifth year of operation. Switzerland privatized its ATC services but did not adopt corporate style techniques involving personnel and equipment procurement.

All subjects indicate safer ATC systems exist due to efficiency resulting from quicker equipment modernization that was not possible under previous bureaucratic governmental procurement policies.

The results can be considered valid because the variables were observed in an uncontrolled and naturalistic state. With an ex post facto design, investigators have no control over the variables in the sense of being able to manipulate (Emory \& Cooper, 1991).

\section{CONCLUSIONS}

This study indicated that ATC privatization would reduce operating cost and increase ATC safety. The study focused on the privatized ATC systems of foreign countries and on quasi-government corporations. The trend during the past 15 years toward privatizing badly run government enterprises has gained worldwide momentum (Becker, 1994). The literature review indicated the present ATC system is adequate and hailed as the safest in the world but running it like a corporation would increase efficiency leading to cost reductions. Economic theory recognizes public ownership as a response to the failure of private markets to secure efficient and equitable outcomes (Schwartz \& Lopes, 1993). Failure to secure efficient and equitable outcomes led to government control of the ATC system at the request of the early airlines in 1936 . Efficiency and safety were the driving forces. Studies involving various countries by Schwartz and Lopes (1993) indicate that privatization results have fallen short of expectations, particularly with respect to privatization proceeds; but, more likely, expectations were exaggerated to begin with.

There is little reason to doubt that privatization would increase efficiency thus reducing operating cost and increasing safety. Reduced operating cost would also come from personnel reductions and efficient equipment procurement procedures not requiring present bureaucratic red tape. The literature review indicated new equipment purchases would not have been possible under previous rigid systems tied to government budgets. New state of the art equipment would definitely increase safety regarding air traffic control.

\section{RECOMMENDATIONS}

The results of this study support the hypothesis that reduced operating cost and increased safety would result from the privatization of the U.S. ATC system. The 
privatized system as proposed would employ corporate style equipment procurement and personnel management techniques rather than present-day bureaucratic techniques. These recommendations based on the results of this study are:

1. The proposed proposal is implemented as a separate ATC service from the FAA.

2. The separate ATC service is structured as a nongovernment corporation employing corporate style personnel management and equipment procurement techniques.
3. The FAA maintains responsibility for safety and oversight of the ATC system.

4. Additional studies conducted to determine what effect privatization will have on national security.

Despite the work of others and the existence of related work, this research constituted a different approach to the ATC privatization issue. It attempted to analyze the existing data scientifically to reach conclusions concerning the privatization of the Air traffic Control System in the United States. $\rightarrow$

Anthony Adams is the aviation program coordinator and assistant professor of Aviation at the Eastern Kentucky University in Richmond, Kentucky. He holds a Master of Aeronautical Science degree from Embry-Riddle Aeronautical University. He is a retired United Army pilot and possesses an FAA Commercial pilot's certificate for airplanes and helicopters. During his aviation career, he has accumulated over 6200 flight hours as a pilot, instructor pilot and flight evaluator. 
FIGURE 1

MILL'S CANNON OF DIFFERENCE

$\begin{array}{ll}A=\text { privatized personnel management technique } & \text { (IV) } \\ \mathrm{B}=\text { privatized equipment procurement technique } & \text { (IV) } \\ \mathrm{C}=\text { decrease in operating cost } & \text { (DV) } \\ \mathrm{D}=\text { increase in operating cost } & \text { (DV) } \\ \mathrm{E}=\text { increase in flight safety } & \text { (DV) } \\ \mathrm{F}=\text { increase efficiency } & \text { (DV) }\end{array}$

Australia

Germany $=$ GE

New Zealand $=$ NZ

Switzerland $=\mathrm{SW}$

$\mathrm{AU} \quad \mathrm{A}$ and $\mathrm{B} \longrightarrow \mathrm{C}$

$\mathrm{GE} \quad \mathrm{A}$ and $\mathrm{B} \longrightarrow \mathrm{C}$

$\mathrm{NZ} A$ and $\mathrm{B} \longrightarrow \mathrm{C}$

SW No $A$ and $B \longrightarrow$ No C

Therefore $\mathrm{A} \longrightarrow \mathrm{C}$

$A$ causal relationship exist between $A$ and $C$.

$\mathrm{AU} \quad \mathrm{A}$ and $\mathrm{B} \longrightarrow \mathrm{E}$

$\mathrm{GE} \quad \mathrm{A}$ and $\mathrm{B} \longrightarrow \mathrm{E}$

$\mathrm{NZ} A$ and $\mathrm{B} \longrightarrow \mathrm{E}$

SW No $A$ and $B \longrightarrow E$

Therefore $\mathrm{B} \longrightarrow \mathrm{E}$

$A$ causal relationship exists between $B$ and $E$.

There is no relationship between $A$ and $E$.

$\mathrm{AU} A$ and $\mathrm{B} \longrightarrow \mathrm{F}$

$\mathrm{GE} A$ and $\mathrm{B} \longrightarrow \mathrm{F}$

$\mathrm{NZ} A$ and $\mathrm{B} \longrightarrow \mathrm{F}$

$\mathrm{SW}$ No $\mathrm{A}$ and $\mathrm{B} \longrightarrow \mathrm{F}$

Therefore $\mathbf{B} \longrightarrow$ F

$A$ causal relationship exists between $B$ and $F$.

There is no relationship between $A$ and $F$.

$\mathrm{AU} \quad \mathrm{A}$ and $\mathrm{B} \longrightarrow$ NoD

$\mathrm{GE} \quad \mathrm{A}$ and $\mathrm{B} \longrightarrow$ No $\mathrm{D}$

$\mathrm{NZ} \mathrm{A}$ and $\mathrm{B} \longrightarrow \mathrm{NoD}$

$\mathrm{SW}$ No $\mathrm{A}$ and $\mathrm{B} \longrightarrow \mathrm{D}$

Therefore No A $\longrightarrow$ D

$A$ causal relationship exists between $N_{0} A$ and $D$. 


\section{REFERENCES}

Air Traffic Controller's Handbook. (2004). Washington, DC: U.S. Government Printing Office.

Becker, G. S. (1994, June 20). Neither rain nor sleet nor good idea shall shake up the postal system. Business Week, p. 26 Boyer, P. (1994, June). ATC, inc.-round one. Aircraft Owners and Pilots Association, p. 2.

Chang, S. Y., Jones, R. A. (1992). Approaches to privatization: established models and a u.s. innovation. Government Finance Review, $\underline{8}$ (4), 17-21.

Change, challenge, and competition. $\quad$ (1993, October/November). Air Line Pilot, p. 34.

Collogan, D. (1994, July). USATS: politics and promises. Business \& Commercial_Aviation, p. 88.

Dempsey, P. S., \& Goetz, A. R. (1992). Safety. Airline deregulation and laissez-faire mythology (p. 300). Westport, CT: Quorum.

Emory, C. W., \& Cooper, D. R. (1991). Business research methods (4th ed. Boston: Irwin.

Facts On File. (1993, August 26). United States: Aviation. (Vol. 53, p. 632). New York: Oxford.

Federal air regulations. 2004. Part 1. Washington, DC: U.S. Government Printing Office.

Gilbert, A G. (1994, April). Opinions are mixed toward an atc government corporation. Business \& Commercial Aviation, p. 17.

Hazelwood, E., (1994, May 16). Global support grows for private atc companies. Aviation Week \& Space Technology. p. 45.

Kane, R. M., \& Vose, A. D. (1982) Air transportation. (8th ed.). Dubuque, IA: Kendall/Hunt.

Kommons, N. K. (1978). Bonfires to beacons. Washington, DC: U. S. Government Printing Office.

Leedy, P. D. (1993). Practical research planning and design. (5th. ed). New York: Macmillan Publishing Company

Lenorovitz, J. M., \& Phillips, E. H. (1994, January 10). Clinton compromises on airline strategy. Aviation Week \& Space Technology, p. 22.

Mecham, M. (1974, May 16). Airways corp. leads way in atc commercialization. Aviation Week \& Space Technology, pp. 42-43.

Nolan, M.S. (2004). Fundamentals of air traffic control. (4 ${ }^{\text {th }}$. Ed). Belmont, CA: Brooks/Cole-Thomson Learning.

Phillips, E. H. (1994, May 16). Flexible policy key to atc corporation. Aviation Week \&_Space Technology, pp. 36-37.

Schwartz, G., \& Lopes, P. S. (1993, June). Privatization: expectations, trade-offs, and results. Finance \& Development, p. 14. Shepard, J. M. (1981). Research methods: the sociologist as detective. Sociology (pp. 27-45). St Paul: West Publishing Co. Solberg, C. (1979). Conquest of the skies. Boston: Little Brown and Company. 
Wells, A. T., (1994). Air transportation a management perspective (p. 101). Belmont, CA: Wadsworth.

Wells, A. T., (1986). The airport-airway system: a historical perspective. Airport planning and management (pp.3-31). 